\title{
A Study on Flipped Classroom-based Autonomous Learning Model Applied in English Visual-audio-oral Teaching
}

\author{
Ming Cai \\ School of Foreign Languages \\ Xinyang Agriculture and Forestry University \\ Xinyang, China
}

\begin{abstract}
This paper aims to construct a flipped classroombased autonomous learning model in English visual-audio-oral teaching with the expectation that some inspirations and references can be offered to English educators. Taking flipped classroom as the carrier, this model tries to carry out autonomous learning, knowledge internalization and knowledge consolidation and development from both teachers and students' perspectives.And the effectiveness of the model are evaluated from the level of students' listening and speaking ability.
\end{abstract}

Keywords - listening competence and oral proficiency; flipped classroom; autonomous learning; English visual-audio-oral teaching

\section{INTRODUCTION}

With the rapid development of multimedia technology and information technology such as mobile learning, distance learning, e-learning, ubiquitous learning and the growing popularity of intelligent education, the College English Teaching reform has been further promoted. College English autonomous learning model and flipped classroom are two of the most important developing trends in the process of the education reform. It is described in the latest College English Curriculum Requirements that goals of college English teaching are focused on the cultivation of students' integrated use of English, particularly their proficiency in listening and speaking, the promotion of their competency to exchange information both orally and on paper, the enhancing of their autonomous and self-directed learning abilities, the upgrading of their cultural awareness and attainments, and their adaptation to the needs of China's national economy development and international exchange. However, at present, students' improvement of listening comprehension competence and oral proficiency is not sufficient, for the lack of relatively more efficient teaching methods applied to the English visualaudio-oral course. One of the best ways for the teacher to improve the students' autonomous learning ability and listening proficiency is to employ an appropriate English teaching and learning model to encourage students to improve their listening and speaking abilities as well as autonomous learning ability. Meanwhile, as China's increased enrollment of college and university, teachers find it increasingly hard to cater to each student's learning requirements. Consequently, several problems such as chaotic discipline and disordered activities organization take place. Except that, there is few chances for students to practice and express themselves. Gradually, more and more students lose their learning interest and enthusiasm either to practice their ears or to open their mouth. Moreover, out-of-date teaching design and old teaching model also lead to low attendance rate and negative teaching effect. In a word, the current situation of English visual-audiooral teaching can not meet the goals that college English education expects, so it is necessary for teachers to think out creative new models to bring some innovation to their classes.

On the basis of constructivism theory and humanism theory, this paper studies deeply on the construction of a flipped classroom based autonomous learning model and its effectiveness when applied to English visual-audio-oral teaching. As for the significance of the research, it can be summarized from the following aspects.First, provide references for designing the teaching model used in English visual-audio-oral course with the tendency of flipped classroom. Second, with the help of the new model,to foster the students' autonomous learning ability in language learning;Third, to lay foundations for the further study on autonomous learning and flipped classroom.

\section{LITERATURE REVIEW AT HOME AND ABROAD}

\section{A. Research on Flipped-classroom and Autonomous Learning}

In 2007, Jonathan Bergmann and Aaron Sams, chemistry teachers in Woodland Park High School, began to record lessons and posted them online in order to make-up missed lessons for the students who absent from class. Surprisingly, these courses online became popular with students in a very short time. Students made full use of these online materials such as for review and reinforce of classroom lessons. This idea of flipping the common instructional approach is named "the flipped classroom". In the flipped classroom, the traditional classroom is inverted through"moving the lectures outside the classroom and using learning activities to move practice with concepts inside the classroom" (Strayer 2012).

Compared with related researches abroad, with the help of educational technology, some Chinese educators have also been implementing the flipped classroom. Just like education reforms being carried out in Chongqing Jukui Middle School, 
Shenzhen Nanshan Experimental School, and Jiulong Middle School of Nanjing, flipped classroom gets popular and popular in China.

Autonomous learning, also called self-directed learning or learner autonomy, originated in the 1960s. Since Holec's Autonomy and Foreign Language Learning was published in 1981, the concept of autonomous leaning has been set up and in the later 20 years.It has been widely discussed in the field of language learning. Holec (1981: 3) has taken an initial study and elaborated on the definition as: "take charge of one's own learning is to have and to hold the responsibility for all the decisions concerning: determining objectives, defining contents and progressions, selecting methods and techniques to be used, monitoring procedure of acquisition and evaluating what has been acquired." His views base on the responsibility and capacity of learners, and as a starting point, arouse the subsequent studies in this area.

In recent years, more and more Chinese researchers have tried to do researches on various aspects of autonomous learning. After the 1990s, some important study activities on autonomous learning have been operated by teachers and educators such as Pi Dina, Wang Yong, Pang Weiguo and others, which influenced the latest twenty years development. Nowadays, how to make use of modern educational technology to promote foreign language autonomous learning has been paid much attention to by researchers and educators. But there is still a lot of space to explore of autonomous learning. In practical teaching, as for students, it is still difficult for them to take full responsibility for their own learning, and there is still a far cry from the true sense of the autonomous learning model.

\section{B. Research on Flipped Classroom-Based Autonomous Learning Model Applied in English Visual-audio-oral Teaching}

Although many references could be found out on flipped classroom,autonomous learning as well as English visualaudio-oral teaching, there is few foreign literature on how to construct an autonomous learning model and apply it into English visual-audio-oral teaching with the basis of flipped classroom.Therefore, there is a far cry from exploring towards this aspect.

By March 2017, data related to this research can be found from the database of CNKI (China national knowledge internet).And it shows as follows:

TABLE I. LITERATURE REVIEW

\begin{tabular}{|c|l|l|l|l|l|}
\hline $\begin{array}{c}\text { Type of } \\
\text { Kournals/piece }\end{array}$ & $\begin{array}{c}\text { Journ } \\
\text { al }\end{array}$ & $\begin{array}{c}\text { Degr } \\
\text { ee }\end{array}$ & $\begin{array}{c}\text { Confer } \\
\text { ence }\end{array}$ & $\begin{array}{c}\text { Newpa } \\
\text { per }\end{array}$ & Total \\
\hline $\begin{array}{c}\text { Klipped classroom } \\
\text { autonomous learning } \\
\text { model }\end{array}$ & 8820 & 700 & 189 & 62 & 9771 \\
\hline $\begin{array}{c}\text { English visual-audio- } \\
\text { oral teaching }\end{array}$ & 819 & 70 & 9 & 1 & 899 \\
\hline $\begin{array}{c}\text { The three keywords } \\
\text { above together as } \\
\text { keywords }\end{array}$ & 2 & 0 & 0 & 0 & 2 \\
\hline Soyw this shows & & 331 & 108 & 83 & 4066 \\
\hline
\end{tabular}

So, this shows in recent years, more and more scholars in China pay more attention to the research of the flipped classroom and the autonomous learning model. While less research was done to "English visual-audio-oral teaching", let alone the research on the combination of "flipped classroom" and "autonomous learning model" applied into "English visualaudio-oral teaching". That is to say there are few empirical studies on the systematic model building and the whole teaching design, as well as the teaching effect needs to be further studied. Meanwhile most of previous researches still focus on the courses of linguistics, literature, culture and so on, which are mainly knowledge focused, while for the skillfocused courses like English visual- audio-oral ,there is still a lot worthy of study and exploration. And There is still a far way to go to explore how to make an appropriate and effective combination of flipped-classroom together with autonomous learning. So with the view of this, the purpose of this study is to construct a flipped classroom-based autonomous learning model and apply it to English visual-audio-oral teaching as well as evaluate its effectiveness.

\section{THE APPLICATION OF THE FLIPPED CLASSROOM-BASED AUTONOMOUS LEARNING MODEL IN VISUAL-AUDIO-ORAL TEACHING}

In order to explore a proper model applied to English visual-audio-oral teaching with the help of autonomous learning and flipped classroom, it is necessary to explain the relationship between flipped-classroom and autonomous learning and the features of English audio-visual-oral teaching.

\section{A. Abbreviations and Acronyms}

Define abbreviations and acronyms the first time they are used in the text, even after they have been defined in the abstract. Abbreviations such as IEEE, SI, MKS, CGS, sc, dc, and rms do not have to be defined. Do not use abbreviations in the title or heads unless they are unavoidable.

First, There are shared ideas between flipped classroom and autonomous learning. The flipped classroom changes the traditional teaching process. Teachers provide students with suitable learning materials such as video clips before class and students learn these materials autonomously with their available time out of class. As a language autonomous learner, it is requested to develop his initiative and autonomy, also to experience from spontaneity to initiative and to develop their initiative, enthusiasm, thinking .And these are the same abilities both needed in autonomous learning as well as in flipped classroom.

Second, flipped classroom and autonomous learning are integrated with each other. With the assistance of information technology or traditional means, flipped classroom,realizes the upside-down of knowledge imparting and knowledge internalization compared with the traditional classroom. When the students study the learning materials provided by teachers out of class, they can decide how to learn them according to their own situation, and they can arrange their learning paces. These all show that flipped classroom can let students learn autonomously and that the flipped classroom require students have high autonomous learning ability to manage their learning process. In brief, it is the precondition and prerequisite that students have certain autonomous learning ability in language 
learning for the effective implementation of flipped classroom, which can continually improve students' autonomous learning.

After analyzing the relationship between flipped classroom and autonomous learning mentioned above and the characteristics of English audio-visual-oral teaching, the flipped classroom-based autonomous learning model can be constructed in the next section.

\section{B. Construction of the Flipped Classroom-Based Autonomous Learning Model}

- Based on the theoretical foundation and the previous studies, the researcher tries to formulate an autonomous learning model with the basis of flipped classroom ,and then apply it into the English visual-audio-oral teaching.This teaching model attempts to improve the English visual-audio-oral teaching and to help students develop their autonomous listening ability and improve their listening and speaking ability. This model, shows its features respectively on the aspects of learners' role and teachers' role. Teachers play the role of guides and assistants along the learning process, while the learners are the heroes and heroines. And three stages are included in it, before-class stage,in-class stage and after-class stage. the model was demonstrated with the following picture:

- There are three stages of the autonomous learning model.They are before-class stage,in-class stage and after-class stage.For the first stage ,it mainly focuses on students' autonomous learning. In order to foster students' autonomy in language learning, the teaching resources play a very important role.Their effect and functions can not be ignored. Teachers need to select teaching resources which should be suitable for autonomous learning. on the basis of the analysis of characteristics of learners and learning content, teachers need to to provide students with a wealth of teaching resources such as video clips, PPT, mini-course, micro video and other relevant resources and to give every student some appropriate instructions judging from his learning condition. And the teacher also need to design several learning activities and pre-class targeted practice to guide students to do self-learning. As for students, during the before-class period of autonomous learning,they need to carefully learn the provided teaching resources autonomously, and to complete the relevant exercises and to make it clear about things they have learned, as well as that they haven't understood. And they can make full use of modern technologies such as internet to assist their autonomous learning. Then Students need to let teachers know about their difficulties and problems through on-line or offline communication. At the same time, teachers need to summarize all the problems and questions students asked. As a result, before class, teachers and students both sides of course gives learning goals, is beneficial to learners in autonomous learning, deep understanding of knowledge, the teacher also can better according to their aptitude.
- With the preparation of the first stage, it can move to the second stage of this model, in-class stage, also called during-class stage. For in-class stage, knowledge internalization should be the main goal. teachers need to encourage students to share and communicate with each other about their gains and to discuss and explore the problems by themselves. Meanwhile, teachers should make explanations of the learning points, design the learning and teaching activities such as distributing learning tasks, dividing cooperative learning groups and making assessment criteria. And different learning groups are formed in accordance with the questions students have raised before class. If students cannot solve the problems by themselves, the teacher need to help them with focusing on the difficult points and to assist students in individualized learning. While in during-class stage,there are lots of interactions between teacher and students as well as among students themselves such as students' presentation making or performance giving, groups' communication and communication between the teacher and students, the teacher's comment, the teacher and students' summary of the class and the feedback and evaluation of the learning. That's to say, before and while students making presentation or giving performance, they can make discussion and communication in and among groups. When they encounter problems, they can turn to the teacher. After their presentation or performance, the teacher need to make comments on students' performance while other students can also express their opinions. And then both the teacher and the students need to summarize the whole class learning respectively. When it comes to the end of the class, feedback and evaluations should be done.The students should let the teacher know their feeling,gains and confusions if any as well as their suggestions for the next lesson. As for evaluations(including not only summative evaluation but also formative evaluation) or assessment, It should not not only from the teacher's perspective but also from students' themselves' or peer's perspective.From what have been done during inclass stage, the internalization of knowledge could be realized.

- For the third stage, after-class stage, as for the teacher, it is necessary to make reflective thinking about the design and procedure of the whole class such as the strong points and things need to be improved. And with the experience have gotten, better preparation will be made for the next class. As for the students,after autonomous learning before class and knowledge internalization in class, in this stage, they should focus on the review and consolidation of what have learned, and also on Knowledge development and expansion.That means, they need to make further study autonomously on the related knowledge of what they have got. 


\section{AN EMPIRICAL RESEARCH OF THE FLIPPED \\ CLASSROOM-BASED AUTONOMOUS LEARNING MODEL IN VISUAL-AUDIO-ORAL TEACHING}

\section{A. Research Questions}

This thesis aims to build a new autonomous learning model based on flipped classroom and to apply it to the English visual-audio-oral teaching, as well as to investigate the effectiveness of the new model. Specifically, the research is designed and carried out to answer the following four questions:

1) Is this flipped classroom-based autonomous learning model more effective than the traditional teaching method when applied to the English visual- audio-oral teaching?

2) Are the students' listening and oral competence and proficiency improved with the application of the new model?

\section{B. Research Subjects}

The subjects of this research are 74 sophomore majoring in Applied English in Xinyang Agriculture and Forestry University. They were from the similar background, and they used the same textbook-New Horizon College English Viewing, Listening and Speaking Book 2 by Foreign Language Teaching and Research Press and they are also under the guidance of the same teacher(the researcher) following the shared teaching syllabus. And they have the same learning experience in English visual-audio-oral course under the traditional way of teaching. That is to say, they are in 2 paralleled classes set as control class (37 subjects) and experimental class (37 subjects). This experiment is carried out in the first semester of academic year of 2016/2017.

\section{Research Instruments}

This In order to measure students' listening and speaking ability improvements made by the new teaching model of autonomous listening based on flipped classroom as well as its effectiveness and collect reliable information about the experiment in visual-audio-oral course, five primary instruments were involved in the experimental study to yield the research data: two tests of listening comprehension and two tests of oral English proficiency (the pre-tests and the posttests).

Before the experiment, the two classes received a listening comprehension test which was held by the author of the thesis. After one term (14 weeks)of the experiment, the two classes received another listening comprehension test by the author again. And the two tests are adopted from the College English Test Band 4 (CET4 for short), listening part. They were employed as a measurement of the participants' listening comprehension competence. Similar to listening comprehension, students' English speaking abilities were also tested before and after the experiment. Marks were recorded to see whether the new model can help improve the students' English speaking performance.

\section{DATA ANALYSIS AND CONCLUSION}

In terms of test, whether the average listening and speaking proficiency of the two selected class is of approximately equal is tested by pre-test. And it ensures the validity of post-test results. After the experiment, post-test is implemented to investigate the validity of the present teaching and learning model.

TABLE II. GROUP STATISTICS

\begin{tabular}{|c|l|l|l|l|}
\hline Class & \multicolumn{1}{|c|}{ N } & \multicolumn{1}{|c|}{ Mean } & Std.Deviation & Std.Error Mean \\
\hline Control class & 37 & 71.6486 & 8.96356 & 1.47360 \\
\hline $\begin{array}{c}\text { Experimental } \\
\text { class }\end{array}$ & 37 & 72.3514 & 9.29222 & 1.52763 \\
\hline
\end{tabular}

TABLE III. INDEPENDENT S AMPLES T-TEST

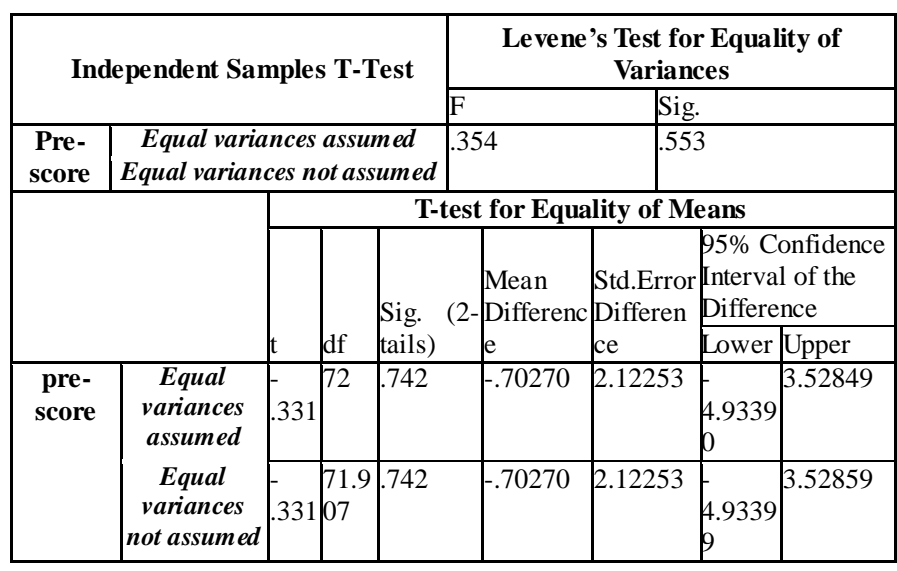

TABLE IV. GROUP STATISTICS

\begin{tabular}{|c|l|l|l|l|}
\hline Class & \multicolumn{1}{|c|}{$\mathbf{N}$} & \multicolumn{1}{|c|}{ Mean } & \multicolumn{1}{|c|}{ Std.Deviation } & \multicolumn{1}{c|}{ Std.Error Mean } \\
\hline Control class & 37 & 71.1351 & 9.59792 & 1.57789 \\
\hline $\begin{array}{c}\text { Experimenta } \\
\text { l class }\end{array}$ & 37 & 74.5946 & 9.52616 & 1.56609 \\
\hline
\end{tabular}

TABLE V. INDEPENDENT S AMPLES T-TEST

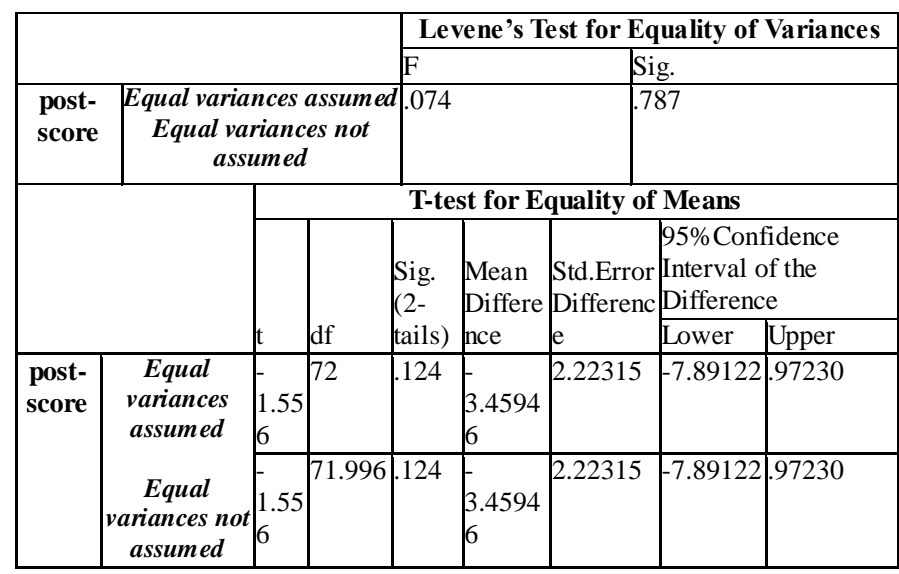

TABLE VI. COMPARISON BETWEEN GROUPS

\begin{tabular}{|c|l|l|l|l|}
\hline \multirow{2}{*}{ Class } & \multicolumn{2}{|c|}{ Pre-test } & \multicolumn{2}{c|}{ Post-test } \\
\cline { 2 - 5 } & Mean & $\begin{array}{c}\text { Std.Deviatio } \\
\boldsymbol{n}\end{array}$ & Mean & Std.Deviation \\
\hline $\begin{array}{c}\text { Control } \\
\text { class }\end{array}$ & $\begin{array}{l}71.64 \\
86\end{array}$ & 8.96356 & 71.1351 & 9.59792 \\
\hline $\begin{array}{c}\text { Experimen } \\
\text { tal class }\end{array}$ & $\begin{array}{l}72.35 \\
\mathbf{N}\end{array}$ & 9.29222 & 74.5946 & 9.52616 \\
\hline $\mathbf{N}$ & 37 & 37 & \\
\hline
\end{tabular}

"Table II" and "Table III" show that students in both classes are at the same listening proficiency level before the 
experiment being carried out. 14 weeks later, a post-test of listening comprehension was conducted to both the control and the experimental class. "Table IV, and "Table V" show that although there is no significant difference between the mean scores in the two tests, the experimental class made a little progress of listening comprehension while on the contrary, the control class did worse in listening comprehension than that of the beginning.

TABLE VII. GROUP STATISTICS

\begin{tabular}{|c|c|c|l|l|}
\hline Class & $\mathbf{N}$ & Mean & Std.Deviation & Std.Error Mean \\
\hline Control class & 37 & 66.2162 & 8.26685 & 1.35906 \\
\hline Experimental class & 37 & 66.5135 & 8.40510 & 1.38179 \\
\hline
\end{tabular}

TABLE VIII. INDEPENDENT SAMPLES T-TEST

\begin{tabular}{|c|c|c|c|c|c|c|c|c|}
\hline & \multicolumn{4}{|c|}{ Levene's Test for Equality of Variances } \\
\hline & & & & & \multicolumn{2}{|c|}{$\mathrm{F}$} & \multicolumn{2}{|c|}{ Sig. } \\
\hline $\begin{array}{l}\text { Pre- } \\
\text { score }\end{array}$ & \multicolumn{4}{|c|}{$\begin{array}{c}\text { Equal variances } \\
\text { assumed } \\
\text { Equal variances not } \\
\text { assumed } \\
\end{array}$} & & \multicolumn{2}{|l|}{.943} \\
\hline & & \multicolumn{7}{|c|}{ T-test for Equality of Means } \\
\hline & & \multirow[b]{2}{*}{$\mathrm{t}$} & \multirow[b]{2}{*}{ df } & \multirow{2}{*}{$\begin{array}{l}\text { Sig. } \\
(2- \\
\text { tails })\end{array}$} & \multirow{2}{*}{$\begin{array}{l}\text { Mean } \\
\text { Differe } \\
\text { nce }\end{array}$} & \multirow{2}{*}{$\begin{array}{l}\text { Std.Error } \\
\text { Differenc } \\
\text { e }\end{array}$} & $\begin{array}{l}95 \% \text { Con } \\
\text { Interval o } \\
\text { Difference }\end{array}$ & $\begin{array}{l}\text { idence } \\
\text { the }\end{array}$ \\
\hline & & & & & & & Lower & Upper \\
\hline \multirow[t]{2}{*}{$\begin{array}{l}\text { pre- } \\
\text { score }\end{array}$} & \multirow{2}{*}{$\begin{array}{c}\text { Equal } \\
\text { variances } \\
\text { assumed } \\
\text { Equal } \\
\text { variances } \\
\text { not } \\
\text { assumed }\end{array}$} & \begin{tabular}{|l|}
15 \\
3
\end{tabular} & 72 & 879 & -.29730 & 1.93814 & -4.16091 & 3.56632 \\
\hline & & 3 & $\begin{array}{l}71.9 \\
80\end{array}$ & 879 & -.29730 & 1.93814 & -4.16093 & 3.56633 \\
\hline
\end{tabular}

TABLE IX. GROUP STATISTICS

\begin{tabular}{|c|c|c|c|c|}
\hline Class & $\mathbf{N}$ & Mean & $\begin{array}{c}\text { Std.Deviati } \\
\text { on }\end{array}$ & Std.Error Mean \\
\hline Contrl class & 37 & 67.6486 & 8.05956 & 1.32498 \\
\hline Experimental class & 37 & 75.2703 & 9.32633 & 1.53324 \\
\hline
\end{tabular}

TABLE $X . \quad$ INDEPENDENT SAMPLES T-TEST

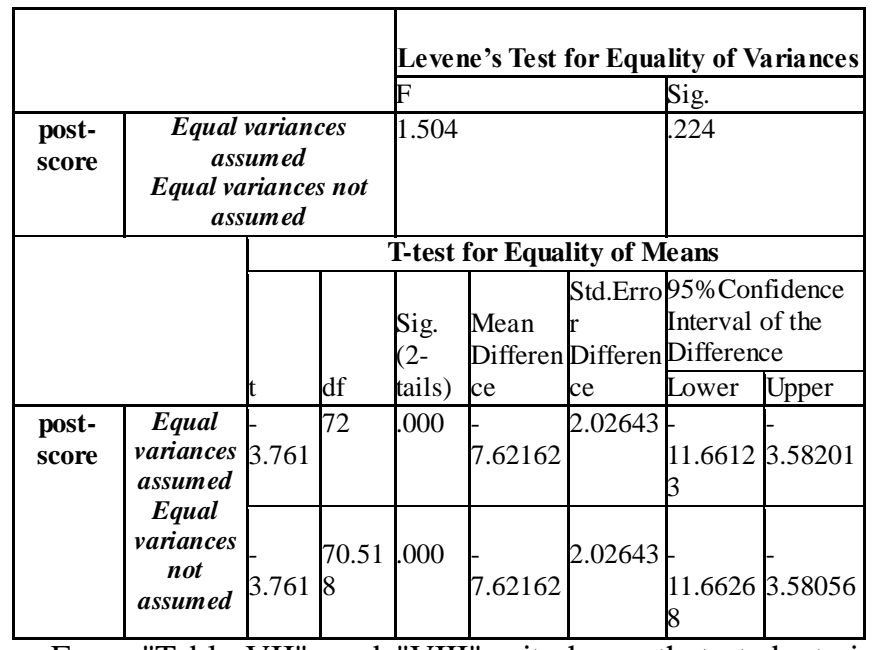

From "Table VII", and "VIII" , it shows that students in both classes are at the same oral proficiency level before the experiment being carried out. And Table "IX, X" shows the level of significance is $\mathrm{p}=0.000$, which is lower than 0.005 , even lower than 0.001 , so it can be concluded that there is significant difference between scores of the two classes. That is to say with the application of the new autonomous learning model, the oral proficiency of the experimental class was improved a lot.

In summary, the flipped classroom-based autonomous learning model is able to facilitate the development of students' language competence in terms of listening comprehension proficiency and oral competence. The data analysis of pre-tests and post-tests shows that both the students' listening comprehension competence and oral proficiency from the experimental class made greater progress than that from the control class, which can also give an answer to the research question "Whether the new model can improve students' listening and oral competence and proficiency?". And It should be noted that subjects under the new teaching model have made greater progress than those receiving traditional teaching method which can be proved by the independent sample $\mathrm{T}$ test and pared sample T test, a comparison is presented concerning the speaking and oral post-test results of the two classes. A conclusion can be drawn that the new model is more effective than the traditional one in terms of listening and speaking instruction, which can offer an answer to the first research question that the effectiveness of the new autonomous learning model.

\section{ACKNOWLEDGMENT}

Special gratitude goes to my students for their support and cooperation throughout the whole research and teaching. And sincere gratitude goes to my beloved family.Without their support, I could not have come so far.

\section{REFERENCES}

[1] Holec H. Autonomy and foreign language learning[M]. Oxford: Pergamon Press, 1981.

[2] Benson, P. Teaching and Researching Autonomy in Language Learning [M]. Harlow: Pearson Education Limited, 2001.

[3] Jeremy F. Strayer. How learning in an inverted classroom influences cooperation, innovation and task orientation [J]. Learning Environ Res, 2012.

[4] Malley J M, Chamot A U. Learning strategies in second language acquisition[M].Cambridge:Cambridge University Press, 1990.

[5] New London Group. A Pedagogy of Multiliteracies: Designing Social Futures [J].Harvard Educational Review, 1996, 66 (1):60-92.

[6] Nunan, D. Second Language Teaching and Learning [M]. Beijing: Foreign Language Teaching and Research Press, 2001.

[7] Ur P. A course in language teaching: practice and theory [M]. Beijing: Foreign Language Teaching and Research Press, 2000.

[8] X. D. Wang, and C. J. Zhang. "The application research of flipped classroom in university teaching: A case study on professional English of educational technology" [J]. Modern Educational Technology, 2013, 23 (8): 11-16. 